\title{
Article \\ A Study on Pei Yue and His Poems Written to Monks
}

\author{
Ludi Wang and Yongfeng Huang *
}

Department of Philosophy, College of Humanities, Xiamen University, Xiamen 361005, China; sdlgdxwangludi@163.com

* Correspondence: yongfeng_huang1976@163.com

\section{check for}

updates

Citation: Wang, Ludi, and Yongfeng Huang. 2022. A Study on Pei Yue and His Poems Written to Monks. Religions 13: 194. https://doi.org/ $10.3390 /$ rel13030194

Academic Editor: Xiaohuan Zhao

Received: 17 November 2021

Accepted: 21 February 2022

Published: 24 February 2022

Publisher's Note: MDPI stays neutral with regard to jurisdictional claims in published maps and institutional affiliations.

Copyright: (C) 2022 by the authors. Licensee MDPI, Basel, Switzerland. This article is an open access article distributed under the terms and conditions of the Creative Commons Attribution (CC BY) license (https:// creativecommons.org/licenses/by/ $4.0 /)$.

\begin{abstract}
Pei Yue 裴説 is a poet who flourished in the Late Tang (618-907) and Five Dynasties (907-960). The historical literature contains relatively limited information about his life, and his poems handed down to this day are also rare. To date, he has not been a major focus in the academic literature. Eight complete poems and two remnants from Pei Yue's existing poems were addressed to monks, including the renowned monk and calligrapher Huaisu 懷素 (737-?), the two outstanding monks and poets Guanxiu 貫休 (832-912) and Shangyan 尚顔 (fl. 881), as well as the lesser known Chubin 處賓, Chumo 處默, Zhiqian 知乾, a nameless monk always in his monastery (bu chuyuan seng 不出院僧), and Su Zhan 蘇瞻, who was an advanced scholar (jinshi 進士) and planned to become a monk. It can be seen from these poems that Pei Yue often associated with monks: he discussed Buddhist concepts and artistic skills with them, and he both praised and mourned them. Moreover, Pei Yue was strongly averse to worldly life and yearned for a peaceful and pure land. He understood the intricacies of a number of Buddhist concepts, such as "emptiness" ( $w u$ 無) and "mind" ( $x i n$ 心). He sometimes compared and combined Buddhist theories with poetic creation.
\end{abstract}

Keywords: Pei Yue; poems; Buddhism; monks; social association

\section{Introduction}

No existing historical record reveals the year of Pei Yue's birth or death, and many history books summarize his life in a few words: Pei Yue became the Number One Scholar (zhuangyuan 狀元) in the third year of Tianyou 天祐 (906) in the Tang Dynasty ${ }^{1}$ he once served as Rectifier of Omissions (Buque 補關) and Vice Director in the Ministry of Rites (Libu yuanwailang 禮部員外郎), and he often wandered among "civilian society" (jianghu 江湖) because his official career was hindered by war (Jiang 1981, p. 807). Academic circles have paid little attention to Pei Yue thus far due to his lack of reputation as a poet. Only two journal papers take Pei Yue and his poetry specifically as research objects. Shi Shengnan 史盛楠 (Shi 2014) classifies Pei Yue's poems into the following categories, interpreting each category with simple examples: "poems chanting things and depicting ambitions", "poems describing traveling or sceneries", "poems expressing emotions", "poems on history", "farewell poems", "poems showing quiet life in monasteries" and "poems recording communication with friends". Wu Haiyuan 吳海源 (Wu 2018) explores the "contents", "thoughts" and "artistic styles" of Pei Yue's "poems describing traveling or sceneries", "Buddhist and Daoist poems", "poems recording current events" and "mourning poems". He emphasizes that Pei Yue's poems have the characteristics of "thinking hard, polishing words and desiring for novelty". He also laconically analyzes Pei Yue's two poems “Mourn Monk Chumo" (Ku Chumo shangren 哭處默上人, Peng et al. 1960, p. 8267) and "See off Advanced Scholar Su Zhan Who Will be a Monk After War" (Song jinshi Su Zhan luanhou chujia 送進士蘇瞻亂後出家, Peng et al. 1960, p. 8263), which will be elaborated upon by the authors of the present paper in the following text, and he claims that "Pei Yue's Buddhist and Daoist poems are limpid and ethereal, Pei Yue seems to be a person free from vulgarity". 
Buddhism was prosperous in the Tang Dynasty; at that time, scholars often communicated with and created many poems for monks. By examining these poems, we can learn more about the causes, process and aims of their association, their lives, beliefs and hobbies, as well as some other notions, such as the political context and current affairs in the Tang Dynasty. Although Pei Yue's existing poems are sparse, those written to monks constitute a large proportion of these. From Pei Yue's poems for monks, we know that he interacted with monks not only because of his religious belief or interest, but also because he regarded monks as intimate friends and even confidants. Therefore, Pei Yue expressed worship, admiration, mourning and pity for monks. He generously eulogized a monk calligrapher, discussed poetry with a monk poet, memorialized a dead monk and interacted with a scholar who would later become a monk and, thus, achieve liberation.

Although some of these poems bear no direct relationship to Buddhist doctrines, they concern monks, and since monks are an indispensable part of Buddhism, all of Pei Yue's poems for monks, in this sense, bear a close relationship with Buddhism. In short, both Buddhist ideas and figures are expressed and embodied in Pei Yue's poems for monks. In addition, Pei Yue compared poetic creation with Buddhist doctrines or dharma practices, which revealed his unique theory of creation and his comprehension of Buddhism. Most importantly, he identified some common ground between poetic creation and Buddhism, proving that the two are similar in some ways. Thus, performing in depth research on Pei Yue's poems for monks represents a good starting point from which to explore the relationship between Buddhism and the poetry of the Tang Dynasty.

\section{Pei Yue's Poetic Creation}

Pei Yue's poems describe his experiences and characteristics in more detail. Thus, further information about Pei Yue's life, work and thought can be drawn from his poetry.

The 720th juan of the Comprehensive Collection of Tang Poetry (Quan Tangshi 全 唐詩, Peng et al. 1960, pp. 8260-70) records Pei Yue's fifty-one complete poems and twenty-one remnants; A Supplement to the Comprehensive Collection of Tang Poetry (Quan Tangshi buyi 全唐詩補逸, Sun 1982, p. 229; 1992, pp. 251-52) records one complete poem by Pei Yue; A Further Supplement to the Comprehensive Collection of Tang Poetry (Quan Tangshi xu buyi 全唐詩續補遺, Tong 1982, p. 539; 1992, pp. 444-45) records his one complete poem and two remnants; A Continuation of the Supplement to the Comprehensive Collection of Tang Poetry (Quan Tangshi xushi 全唐詩續拾, Chen 1992, p. 1330) records his two complete poems. Four problems should be noted here.

Firstly, in the Comprehensive Collection of Tang Poetry, Pei Yue's poem "Written to a Like-Minded Friend Under Mount Hua on a Spring Morning" (Chunzao ji huaxia tongren 春早寄華下同人, Peng et al. 1960, p. 8261) and Tang Yue's 湯悦 (912-984) poem of the same name (Peng et al. 1960, p. 8616) are similar in content. According to Tong Peiji 佟培基 (Tong 1996, p. 506), this poem may have been written by Tang Yue.

Secondly, in the Comprehensive Collection of Tang Poetry, the last two couplets of Pei Yue's "A Monk Who Never Goes out of Monastery" (Bu chuyuan seng 不出院僧, Peng et al. 1960, p. 8266) are the same as those of Cao Song's 曹松 (828-903) “Written to Mr. Li Who is a Scholar Without Official Position" (Ji Li chushi 寄李處士, Peng et al. 1960, p. 10011). Tong Peiji (Tong 1996, pp. 506, 529, 681) roughly suggests that these couplets were created by Pei Yue.

Thirdly, Pei Yue's one complete poem, "Cold Food Day (Editor Adds the Title)" (Hanshi (ti ni) 寒食(題擬)), in A Continuation of the Supplement to the Comprehensive Collection of Tang Poetry (Chen 1992, p. 1330), includes Pei Yue's two remnants, "Some people gently and leisurely play colored balls, some slender women swing high on the swings" (Huaqiu qingcu huzhong di, caisuo gaofei zhangshang shen 畫正輕蹴瑴中地, 
綵索高飛掌上身), which are collected in the Comprehensive Collection of Tang Poetry and entitled “Tomb Sweeping Day" (Qingming 清明, Peng et al. 1960, p. 8270).

Lastly, A Supplement to the Comprehensive Collection of Tang Poetry in the First Supplement to the Comprehensive Collection of Tang Poetry (Quan Tangshi waibian 全唐詩 外編, Sun 1982, pp. 264-65) points out that Pei Yue's “Hear the Sound of Pounding Clothes by Hammering Block" (Wen zhen 聞砧), also known as "Send Clothes to a Frontier Guard" (Ji bianyi 寄邊衣), as presented in the Comprehensive Collection of Tang Poetry (Peng et al. 1960, pp. 8260-61), may have been written by Pei Yuxian 裴羽仙 under the title "Send Warrior's Costume to Husband" (Ji fu zhengyi 寄夫征衣). Zhou Zuzhuan 周祖譔 and Jia Jinhua 賈晉華 (cited in Xin 1990, p. 426) believe the author of this poem to be Pei Yue. A Supplement to the Comprehensive Collection of Tang Poetry in the Second Supplement to the Comprehensive Collection of Tang Poetry (Quan Tangshi bubian 全唐詩補編, Sun 1992), published later, omits this poem.

The authors of the present paper are unable to locate any other poems or remnants by Pei Yue in any other source, so it is concluded that fifty-four complete poems and twenty-one remnants now remain. Nowadays, it can be stated that, compared with other poets who wrote a number of distinguished poems, Pei Yue created only a few and none could be regarded as a masterpiece. However, some poetry reviewers of previous dynasties spoke highly of his work. They praised him for "being famous for poetry" (Ruan 1987, p. 157), and even for "having great poetry fame" (Xin 1990, p. 423); they felt that Pei Yue's poems "think hard about every word carefully" (Ji 1989, p. 1748; 2013, p. 974), "express precisely" (Xin 1990, p. 425) and always "stick to the rules and forms" (Ji 1989, p. 1748; 2013, p. 974). In their opinion, Pei Yue's poetic style is similar to that of Jia Dao 賈島 (779-843) and Li Dong 李洞 (?-fl. 897) (Xin 1990, p. 425). It is worth noting that Hu Zhenheng 胡震亨 (1569-1645) (Hu 1981, p. 80) thought Pei Yue's poems "sometimes included unexpected and amazing lines", and Xin Wenfang 辛文房 (fl.1304) (Xin 1990, p. 425) thought Pei Yue's poems "had fantastic ideas". One of Pei Yue's poems written to a monk, "Ode to Huaisu's Terrace" (Huaisu tai ge 懷素臺歌), also known as “Written on Huaisu's Terrace" (Ti Huaisu tai 題懷素臺, Peng et al. 1960, p. 8260), which will be explored in detail in the following sections, particularly embodies these two features.

There is only one known poem by Pei Yue, "Visit a Daoist" (Fang daoshi 訪道 士, Peng et al. 1960, p. 8264-65), that is related to Daoism. One couplet of this poem, "I have a general understanding of the interest in Daoism and I look forward to frequently talking to you all night" (Cude xuanzhong qu, dangqi suhua pin 粗得玄中趣, 當期宿話頻), tells us that, although Pei Yue was interested in Daoism, he knew little about it. In contrast, Pei Yue has relatively more poems related to Buddhism and monks. He has six poems depicting his visits to monasteries besides his poems written to monks, which will be examined below. In the six poems, Pei Yue described the scenes surrounding the monasteries, such as "The monk's house is on the birds' path, the shadow of the Buddha statue is in the fish pond" (Sengju kua niaodao, foying zhao yutan 僧居跨鳥道, 佛影照魚潭) in “Doushuai Monastery” (Doushuai si 兒率寺, Peng et al. 1960, p. 8265). He presented images of several leisurely monks, e.g., "The secular world is outside the monk's monastery, the monk puts down the curtain, lives leisurely until he grows old" (Duimian fushi ge, chuilian daolao xian 對面浮世隔, 垂 笠到老閒) in “Daolin Monastery" (Daolin si 道林寺, Peng et al. 1960, p. 8265), “The monk walks at a leisurely pace, he goes out in the morning and comes back at dusk" (Gaoseng yin xian (yizuo xian yin) bu, zhouchu xiyang gui (yizuo shi) 高僧引閒(一作閒 引)步, 書出夕陽歸(一作時)) in “Bore Monastery” (Bore si 般若寺, Peng et al. 1960, p. 8265) and "Only the water of Dongting Lake and the old monk's leisure can not be destroyed by war" (Weiyou liangban shao bude, Dongtinghu shui laoseng xian 唯有 兩般燒不得, 洞庭湖水老僧閒) in “Written on Monk's House in Yueyang After War" (Yueyang binghuo hou ti sengshe 岳陽兵火後題僧舍, Peng et al. 1960, p. 8269). Pei Yue also wrote about a moving conversation that he had with a monk: "A monk and 
I recite poetry and talk in autumn, river intersects with sky in the distance" (Yu shi yinlun chu, qiushui jin yaotian 與師吟論處, 秋水浸遙天) in “Written on Monk's House in Yuezhou" (Ti Yuezhou sengshe 題岳州僧舍, Peng et al. 1960, p. 8265). The lines "Why do we care about the generation of afflictions, space is around us" (Heji sheng fannao, xukong shi silin 何計生煩惱, 虛空是四鄰) in “Lumen Monastery" (Lumen si 鹿門寺, Peng et al. 1960, p. 8265) show Pei Yue's comprehension for "space". In Buddhism, "everything is empty and unreal" (Zhu 1990, p. 4), "all phenomena", "all worlds", "all things", "all actions of sentient beings", "all buddhas", "all buddhas' powers", "all meditation concentrations", "all the principles the buddhas teach", "all buddha-bodies" "are like space" (Cleary 1993, p. 875). Pei Yue had some understanding of these Buddhist concepts, suggesting that, since all the things around us are untrue, then the "afflictions" are also untrue; thus, why concern ourselves with their appearance?

All in all, Pei Yue had a close relationship with monks, and Buddhist culture is embodied in his poetry. In the following section, the authors of the present paper will further explore this topic by interpreting Pei Yue's poems for monks. The authors hope that this paper will arouse the interest of academics in Pei Yue's poetry, especially his poetry for monks, in order to facilitate more in depth investigations and reviews of Pei Yue's literary and ideological achievements.

\section{Pei Yue's Poems for Monks}

The authors of the present paper are unable to locate any records of Pei Yue's relationship with Buddhism or monks in the historical literature. However, this omission is compensated for in Pei Yue's poems for monks. Eight complete poems and two remnants that remain today were created by Pei Yue for eight monks.

(1) Huaisu in Pei Yue's "Ode to Huaisu's Terrace":

我呼古人名 I call the names of the ancients;

鬼神側耳聽 Ghosts and Divine Beings listen attentively.

杜甫李白與懷素 Du Fu, Li Bai and Huaisu;

文星酒星草書星 Are the poetry star, liquor star and cursive hand star.

永州東郭有奇怪 There are some special things in the eastern suburb of Yongzhou;

筆冢墨池遺跡在 The ruins of the grave of abandoned writing brushes and the inkwell still exist.

筆冢低低高如(一作似)山 The grave of abandoned writing brushes that looks low is as high as a mountain;

墨池淺淺深如海 The inkwell that looks shallow is as deep as the sea.

我來恨不已 I am feeling deeply regretful.

爭得青天化爲一張紙 How to turn the blue sky into a piece of paper;

高聲喚起懷素書 Wake up Huaisu loudly and make him write on it;

搦管研朱點湘水 With a writing brush dipped in ink which is made from cinnabar with water from the Xiang River.

欲歸家, 重歎嗟 When I am going to return home, I sigh with emotion again. 眼前有三箇字 Three words are in front of me:

枯樹槎、烏梢蛇、墨老鴉 A dead branch, a black snake and a black old crow.

According to Tao Zongyi 陶宗儀 (1329-fl.1412) (Tao 2016, p. 101), Pei Yue was “famous for a calligraphy style between running hand (xingshu 行書) and cursive hand (caoshu 草書)". Since Pei Yue was an expert in calligraphy, his evaluation of Huaisu's calligraphic skill is of great reference value. In Pei Yue's opinion, Du Fu 杜 甫 (712-770), Li Bai 李白 (701-762) and Huaisu occupied the highest positions within the domains of poetry, white liquor and calligraphy, respectively. Their fame was so great that even "ghosts and Divine Beings" admired them. The site where Huaisu buried his "abandoned writing brushes" 2 and hoarded ink was located "in the eastern suburb of Yongzhou" and, according to Pei Yue, was worth visiting. "The grave of 
abandoned writing brushes" was not as high as Pei Yue imagined, and "the inkwell" was not overly deep. However, Pei Yue believed that Huaisu's calligraphy achievements were unparalleled, like high mountains; his connotations were unfathomable, like the depths of the sea, and they could not be measured by how many writing brushes had been worn out or how much ink had been used up. Considering that he had never seen Huaisu's charm with his own eyes, Pei Yue felt regretful; he imagined allowing the reborn Huaisu to write on the sky. When leaving the site, Pei Yue could not help but sigh again. In the final three lines, by describing a sad atmosphere, with a number of desolate images, Pei Yue expressed his sadness, which was brought by Huaisu's death, and his own imminent departure from this place; secondly, Pei Yue considered that art had reached its acme when it became integrated into nature, and that Huaisu's calligraphy had attained such a state, so that every natural scene and creature that Pei Yue saw at Huaisu's site seemed to be one of Huaisu's calligraphy characters.

As mentioned earlier, the comments that Pei Yue's poems "sometimes included unexpected and amazing lines" and "had fantastic ideas" are well reflected in this poem. In addition, in Huang Tingjian's 黃庭堅 (1045-1105) (cited in Hu 1962, p. 125) view, this poem was "especially witty and weird". In this poem, "the grave of abandoned writing brushes" is both low and high; "the inkwell" is both shallow and deep. While appearing contradictory, with these phrases, Pei Yue deftly contrasted what he saw with what he felt. In order to capture the tremendous power of Huaisu's calligraphy, Pei Yue imagined turning the sky into paper and using the river to make ink. The notion of transforming botany and animals into artistic characters is unexpected and artful.

(2) Guanxiu in Pei Yue's "For Guanxiu" (remnants) (Zeng Guanxiu (canju) 贈貫 休(殘句), Peng et al. 1960, p. 8269) and “Written to Guanxiu” (Ji Guanxiu 寄貫休, Peng et al. 1960, p. 8267).

There are two remnants entitled "For Guanxiu" attributed to Pei Yue: "(Shi shi jing jie yi, wei shi hui que nan) 是事精皆易, 唯詩會卻難" state that writing excellent poems is much harder than achieving success in any other task. There also exists Pei Yue's one complete poem, entitled "Written to Guanxiu":

憶昔與吾師 I recall once my master and I;

山中靜(一作精)論時 Discussed in the quiet mountains (or Discussed seriously in the mountains).

總無方是法 Emptiness is the true essence of Buddhism;

難得始爲詩 Only by thinking hard can we create poetry.

凍犬眠乾葉 The dogs shivering in the cold covered themselves with withered leaves to sleep;

飢禽豚病梨 The hungry birds ate rotten pears.

他年白蓮(一作雲)社 One day in the White Lotus (or Cloud) Association;

猶許重相期 I hope we can meet again.

In this poem, Pei Yue recalled conversing with Guanxiu in a quiet location deep in the mountains. If the third word of the second line is jing 精 (deeply and carefully), this couplet indicates that Pei Yue and Guanxiu explored a number of topics in depth and in detail. It is worth mentioning that in two other remnants, "(Kuyin seng ruding, deju jiang chenggong) 苦吟僧入定, 得句將成功” (Peng et al. 1960, p. 8269), Pei Yue states that a person should think hard about his words carefully when writing poems, he can get outstanding work when he achieves an egoless and ideal state, which could be compared to the "concentration" of a monk. The remnants and the second couplet of "Written to Guanxiu" have common features: both of them compare poetic creation with dharma practices, and they consider "thinking hard about every word carefully" as the key to poetic creation. This is consistent with some reviewers' comments on Pei Yue's poems, as cited above, that they have the characteristics of "thinking hard about every word carefully" and "expressing precisely". The second couplet of "Written to 
Guanxiu" even compares the importance of "thinking hard about every word carefully" in poetic creation to the significance of "emptiness" in Buddhism. "Emptiness" is the core ideology in Buddhism and the fundamental characteristic of everything.

The Heart Sutra (Xin jing 心經, Buddhist Wisdom Books: The Diamond Sutra . The Heart Sutra 1972, pp. 85, 89, 93) and The Diamond Sutra (Jingang jing 金剛經, Buddhist Wisdom Books: The Diamond Sutra - The Heart Sutra 1972, p. 59) state, respectively:

Here, O Sariputra, all dharmas are marked with emptiness; they are not produced or stopped, not defiled or immaculate, not deficient or complete. Therefore, O Sariputra, in emptiness there is no form, nor feeling, nor perception, nor impulse, nor consciousness; No eye, ear, nose, tongue, body, mind; No forms, sounds, smells, tastes, touchables or objects of mind; No sight-organ element, and so forth, until we come to: No mind-consciousness element; There is no ignorance, no extinction of ignorance, and so forth, until we come to: there is no decay and death, no extinction of decay and death. There is no suffering, no origination, no stopping, no path. There is no cognition, no attainment and no non-attainment. Therefore, O Sariputra, it is because of his non-attainmentness that a Bodhisattva, through having relied on the perfection of wisdom, dwells without thought-coverings. In the absence of thought-coverings he has not been made to tremble, he has overcome what can upset, and in the end he attains to Nirvana.

Selfless are all dharmas, they have not the character of living beings, they are without a living soul, without personality.

These were what Pei Yue and Guanxiu, being proficient in both Buddhism and poetry, talked about at that time. The "shivering dogs" and the "hungry birds" reflect how harsh Guanxiu's practice environment was. These descriptions express Pei Yue's concern for Guanxiu.

The authors of the present paper believe that the fourth word of the last couplet of this poem should be lian 蓮 (lotus) rather than yun 雲 (cloud), because Baiyun she 白雲社 (White Cloud Association) may have no significant meaning, while a well known allusion can be derived from Bailian she 白蓮社 (White Lotus Association). Sun Changwu 孫昌武 (Sun 2000, p. 10) writes:

It is an important event in the history of Chinese Buddhism for Huiyuan 慧遠 (334-416) and others to form an association. The Biographies of Eminent Monks (Gaoseng zhuan 高僧傳) records: “Liu Yimin 劉遺民 (352-410) of Pengcheng 彭城, Lei Cizong 雷次宗 (386-448) of Yuzhang 豫章, Zhou Xuzhi 周續之 (377-423) of Yanmen 雁門, Bi Yingzhi 畢穎之 (fl. 402) of Xincai 新蔡, Zong Bing 宗炳 (375-443), Zhang Laimin 張萊民 (350-418), Zhang Jishuo 張季碩 (359-423) of Nanyang 南陽 and so on gave up their earthly glory and wealth and followed Huiyuan. Huiyuan held a ceremony to express their longing for Western Paradise in front of the Statue of Amitabha Buddha (Wuliangshou fo 無量壽佛) in the monastery"... The names of “White Lotus Association" and “Eighteen Sages" (Shiba xian 十八賢) did not appear in Huiyuan's day. ... Bai Juyi 白居易 (772-846) tried his best to publicize the legend of "White Lotus Association"... From then on, the allusion related to "White Lotus Association" often appeared in the works of poets and monk poets in the Late Tang and Five Dynasties... The works of Pei Yue, Li Xianyong 李咸用, Li Shanfu 李山甫 (fl. 861), Wu Qiao 伍喬 (fl. 943), Li Zhong 李中 (fl. 920-fl. 974), Li Jianxun 李建勛 (fl. 873-952) and monk poet Guanxiu, Qiji 齊己 (864-fl. 937), Xiumu 修睦 (?-918) and so on frequently used the allusion related to "White Lotus Association".

In the last couplet of this poem, Pei Yue used "White Lotus Association" to refer to the association of monks and common people; here, people from both outside and 
inside the secular world could open their hearts to each other. This couplet indicates that Pei Yue was strongly looking forward to seeing Guanxiu again in this place in the future.

(3) Shangyan in Pei Yue's “Written to Monk Shangyan" (Ji seng Shangyan 寄僧尚顏, Peng et al. 1960, p. 8267):

曾居五老峯 Shangyan once lived in the Five Old Men Peak;

所得共誰同 Who can match his achievements?

才大天全與 His great talents are all given by the Divine Beings;

吟精楚欲空 His poetic skill is incomparable in the area once belonged to the State of Chu.

客來庭減日 Time passes as he chats with guests who come to his courtyard;

鳥過竹生風 Birds fly by the bamboo, which create winds.

早晚搖輕拂(一作金錫) One day in the future, he will shake a light whisk (or hold a golden tin staff);

重歸瀑布中 To return to the waterfall.

Pei Yue passionately eulogized Shangyan's achievements, which, he felt, no one could match. Shangyan lived a leisurely life in the mountains. However, in Pei Yue's eyes, such a leisurely life was not what Shangyan had expected. Pei Yue believed that extraordinary Shangyan would eventually return to the depths of nature and integrate his whole body and mind with nature. Both the "whisk" and the "tin staff" are meaningful in Buddhism. The former is not only an "instrument for flicking away mosquitoes" (Yijing 1990, p. 229), but also a common tool used by prominent monks to admonish ordinary monks and help them learn the dharma (Huiran 1990, pp. 496, 503-4). The Tin Staff Sutra (Dedao ticheng xizhang jing 得道梯橙錫杖經, 1990, p. 724) states: "Past Buddhas held tin staff, future Buddhas will hold tin staff, present Buddhas also hold it". This demonstrates that the "tin staff" is an indispensable item for eminent monks. The Tin Staff Sutra (1990, p. 724) also states: "The tin staff is called the wisdom staff or the morality staff because it displays holy wisdom (shengzhi 聖 智) and creates merit (gongde 功德)". Pei Yue praised Shangyan for his "holy wisdom" and "merit" by describing Shangyan "holding a golden tin staff". Regardless of whether the fourth and fifth words of the last couplet of this poem are "light whisk" or "golden tin staff", this couplet expresses certainty that Shangyan will return to the pure land with Buddhist items and that he is a true Buddhist master.

(4) Chubin in Pei Yue's "Written to Monk Chubin in the South of Dongting Lake" (Huwai ji Chubin shangren 湖外寄處賓上人, Peng et al. 1960, pp. 8266-67):

怪得意相親 No wonder I feel kind to Chubin;

高攜一軸新 He brings a new volume of his poetry.

能搜大雅句 He can use the verses in the Book of Songs · Major Odes (Shijing · Daya 詩經·大雅);

不似小乘人 He seems not to believe in the Lesser Vehicle.

佑麓擎枯檜 Withered junipers stand on the Mount Yuelu;

潚湘吐白蘋 White clover ferns float on the Xiang River.

他年遇同道 If one day we meet on the same road;

爲我話風鹿 I hope you can tell me about your travel experiences.

Chubin shared with Pei Yue his new poetry. After reading, Pei Yue immediately felt unexpected and delightful kindness towards Chubin. Chubin could transform and then draw upon the former poets' beautiful lines when creating his poetry. In the Chinese Buddhist tradition, the so called Lesser Vehicle (Hinayana or xiaocheng 小 乘) is believed to carry oneself only, while the Great Vehicle (Mahayana or dacheng 大 乘) carries all people. ${ }^{3}$ Pei Yue suggested that Chubin "seemed not to believe in the Lesser Vehicle", indicating that Chubin, in his poetry, expressed a desire to save all sentient beings, and that Pei Yue also had the desire to free all the common people. At 
this moment, faced with a bleak scene, Pei Yue said goodbye to Chubin: "If we have the opportunity to see each other in the future, we can chitchat again".

(5) Chumo in Pei Yue's "Mourn Monk Chumo":

溇涼繐幕下 In a desolate atmosphere, under the curtain of the mourning hall;

香吐一燈分 Smoke from burning incense is seperated by the candlelight.

瞏老輸寒檜 Chumo lost to the junipers that were unafraid of the cold in compar-

ing who lived longer;

留閒與白雲 What he left to the clouds was loneliness.

挈孟曾幾度 He held his alms bowl several times;

傳衲不敎焚 And passed on his frock so that it would not be destroyed.

泣罷重回首 After crying, I turn my head again;

暮山鐘半聞 The faint bells ring from the mountains surrounded by the dusk.

When Pei Yue visited Chumo's former residence and saw a forlorn scene, sadness immediately filled his mind. Pei Yue described how junipers were still there, but Chumo was not; when clouds floated over Chumo's residence as usual, they could not see him again. Chumo visited Buddhist holy sites to seek Buddhist essences a few times and imparted his lifelong learning to others to keep truths alive. After some contemplation, Pei Yue wiped away his mourning tears, turned round and looked out into the distance. The vast twilight surrounded the mountains, and the bells rang faintly. Both the circumstances and Pei Yue's mood were gloomy and dismal.

(6) Zhiqian in Pei Yue's “Written to Monk Zhiqian” (Ji seng Zhiqian 寄僧知乾, Peng et al. 1960, p. 8269):

貌高淸入骨 Having natually noble and clear appearance;

帝里舊臨壇 Zhiqian once held Buddhist ceremonies to grant precepts to others in the precept platform ${ }^{4}$ of the capital.

出語經相似 Always talking about the similar Buddhist scriptures;

行心佛證安 He cultivates mind to master the truth of Buddhism.

Consisting of only four lines in twenty Chinese characters, this poem demonstrates Zhiqian's appearance, temperament, past experience and ideas regarding the learning of Buddhism. The Preface of the Collection of the Fundamental Principles of Chan (Chanyuan zhu quan ji douxu 禪源諸詮集都序, Zongmi 2008, p. 22) and the Platform Sutra (Tan jing 壇經, McRae 2000, p. 31) state, respectively:

Bodhidharma (Damo 達摩, ?-536) received dharma from India. When coming to China, he saw most people learning Buddhism here did not inherit dharma, they only took things with entities as explanations and guidelines. Using fingers to point to the moon is like learning dharma through words, moon symbolizes dharma, and fingers symbolize words which are just tools, not the essences. Moon is not on fingers, dharma is not in words, but in my mind. Dharma should be transmitted from mind to mind, not through words. Exotoric Buddhism (Xianzong 顯宗) says this because it advocates eliminating attachments rather than discussing liberation without words and letters.

If a person of the Mahayana or a person of the Supreme Vehicle hears this explanation of the Diamond Sutra, his mind will open forth in enlightened understanding. Therefore, you should understand that your fundamental natures have in themselves the wisdom of prajña. Allowing this wisdom to function of itself in constant contemplation, one therefore need not rely on the written word.

According to the Buddhist classics, the dharma already exists within people's minds. Neither preaching nor practicing dharma should rigidly depend on "words and letters". They also stress that not clinging to "words and letters" does not mean completely abandoning them. Zhiqian was deeply aware of this truth, so he focused 
on cultivating his mind to comprehend Buddhist principles. Based on the Buddhist sutras, Zhiqian paid more attention to expressing his self consciousness and elaborating his own comprehension when discussing dharma.

(7) A monk in Pei Yue's "A Monk Who Never Goes out of Monastery":

四遠參尋徧 Seemingly having visited many places;

修行卻不行 The monk who has high Buddhist cultivation never goes out of monastery.

耳邊無俗語 No vulgar words lingers in his ears;

門外是前生 Previous life is outside the door.

塔見移來影 The moving shadow of the pagoda can be seen;

鐘聞過去聲 The bells that represent the passage of time can be heard.

一齋唯默坐 The monk sits quietly in his meditation chamber;

應笑我營營 I should be laughed at for my busyness.

The monk learned Buddhism and sought truth only in his monastery. Although he never went out, his outstanding achievements made him appear to have been to many Buddhist holy sites. All the people around him were extraordinary, and the inside and outside of his monastery were like two different worlds. The "shadow of the pagoda" moved slowly, and the bells rang at regular intervals, these facts revealed that the outside world was constantly changing. The Platform Sutra (McRae 2000, pp. 45-46) records:

Good friends, what is it that is called meditative concentration (chanding; samādhi)? Externally, to transcend characteristics is "meditation" (chan). Internally, to be undisturbed is "concentration" (ding). If one concentrates on characteristics externally, internally the mind is disturbed. If one transcends characteristics externally, the mind will not be disturbed. The fundamental nature is naturally pure and naturally concentrated; it is only by seeing the realms and thinking of the realms that one is disturbed. If one can see the various realms without the mind being disturbed, this is true concentration.

Good friends, to transcend characteristics externally is "meditation". To be undisturbed internally is "concentration". Externally "meditation" and internally "concentration" is meditative concentration.

This means that human beings' nature is both "pure" and "concentrated", but it is easily disturbed by "characteristics" and "realms". If a person can keep himself away from external interferences and calm his mind through practicing dharma, he can reach the state of "meditative concentration". In the last couplet of this poem, the monk sat in meditation, and external changes did not bother him at all. Pei Yue could not help but laugh at himself: compared with this distinguished monk, he was merely a busy layman in the secular world.

(8) Su Zhan in Pei Yue's "See off Advanced Scholar Su Zhan Who Will be a Monk After War":

因亂事空王 Serving the King of Emptiness because of chaos caused by war;

孤心亦不傷 Su Zhan felt lonely, but not sentimental.

梵僧爲骨肉 The monks will become his close relatives;

柏寺作家㰾 The monastery will be his home.

眼閉千行淚 Countless tears flows from his closed eyes;

頭梳一把霜 His combed hair is as pale as frost.

詩書不得力 Knowledge is of little use;

誰與問蒼蒼 Who should he ask about the way ahead?

The title indicates that this poem was written to Su Zhan, who once was an "advanced scholar" and would become a monk. Therefore, the authors of the present paper regard this poem as one written to a monk. The Surangama Sutra (Lengyan jing 楞嚴經, Buddhist Text Translation Society of Dharma Realm Buddhist Associa- 
tion 2019, p. 252) states: "At that time there was in the world a Buddha named King of Emptiness"; the Meanings of Five Assistance Conditions According to Sutras (Yi jing ming wuzhong zengshangyuan yi 依經明五種增上緣義, Shandao 2013, p. 212) states: "There was a Buddha named King of Emptiness in the past"; and the Collection of the Key Points of Some Sutras (Zhu jing yao ji 諸經要集, Daoshi 1990, p. 2) also states: "There was in the world a Buddha named King of Emptiness a long time ago". It can be seen that "serving the King of Emptiness" refers to converting to Buddhism. The war converted Su Zhan to Buddhism. From then on, he would regard monks as relatives and the monastery as home. According to the last two couplets of this poem, Su Zhan's condition was very depressed; he was tearful and his hair was all white. Learning did not bring him his expected life or allow him to realize his ideals, and he did not know where his future was. The despair delivered in the last couplet belongs not only to Su Zhan and Pei Yue, but also to all scholars who lived during a turbulent time and had no bright future.

\section{Conclusions}

Pei Yue is a lesser known poet during the Late Tang and Five Dynasties. Despite having a scholarly reputation, he has not attracted the attention of academics because he does not have many political achievements or outstanding extant poems. The historical literature documents Pei Yue's life briefly, and there is no record of his religious beliefs or his relationships with religious figures. However, roughly one seventh of Pei Yue's extant poems were written to monks, which shows that Pei Yue closely associated with monks. These poems narrate Pei Yue's discussions of Buddhist theories, poetic skills and the art of calligraphy with monks. They also reveal Pei Yue's feelings for monks: he sincerely eulogized devout monks and sorrowfully mourned a dead monk. Although these poems cannot exactly prove that Pei Yue was himself a devout Buddhist, they express his understanding of Buddhism, to a certain degree.

Pei Yue's poems for monks are full of admiration for the pure land and express helplessness in being unable to escape from an earthly life. This attitude was common among scholars at that time, many famous scholars, such as Wang Wei 王維 (700-761), Bai Juyi and Li Shangyin 李商隱 (fl. 812-858), expressed their desire to convert to Buddhism and their pains brought by the secular world through their poetry. Most of them, on the one hand, tried their best to achieve a good result in the imperial examination and reach the peak of their official careers; on the other hand, they expected to seek liberation in a hermit life or by their religious beliefs because they were tired of chasing fame and wealth. This feeling might have been exacerbated by dynastic changes and wars, which filled the scholars' poems with sadness. In addition, Pei Yue also conveyed his infinite pity and sympathy for those who would become monks. This kind of emotion is difficult to find in the poems of other scholars in the Tang Dynasty. The expression of this complicated and contradictory feeling makes Pei Yue's poems for monks more unique, typical and of more research value.

Author Contributions: Conceptualization, Y.H.; supervision, Y.H.; writing-original draft preparation, L.W.; writing - review and editing, Y.H. All authors have read and agreed to the published version of the manuscript.

Funding: This research was funded by National Social Science Fund of China, grant number: 21AZJ005.

Institutional Review Board Statement: Not applicable.

Informed Consent Statement: Not applicable.

Data Availability Statement: Not applicable.

Conflicts of Interest: The authors declare no conflict of interest. 


\section{Notes}

1 It is believed that Pei Yue became an advanced scholar, even the Number One Scholar, in "the third year of Tianyou (906)" (Chao 1990, p. 935; Chen 1987, p. 580; Xin 1990, pp. 423-25; Xu 1984, pp. 929-33; etc.), “the sixth year of Tianfu 天復 (906)” (Ji 2013, pp. 974, 986; You 1985, pp. 101-2; etc.), "the first year of Tianfu (901)" (Jiang 2019, p. 592) or "the second year of Tianfu (902)" (Sun 1985, vol. 820, p. 272; Ni 2017, p. 6529). After carefully studying some historical materials, the authors of the present paper conclude with certainty that Pei Yue obtained the title of Number One Scholar in the third year of Tianyou in the Tang Dynasty.

2 Li Zhao 李肇 (fl. 813) (Li 2021, p. 161) notes: “Monk Huaisu of Changsha liked cursive hand; he claimed to have found the secret of success of Zhang Zhi 張芝 (?-192CE) who was a famous calligrapher in the Eastern Han Dynasty (25-220CE) and was called the prodigy of cursive hand. Huaisu buried abandoned writing brushes under the mountains and called it 'grave of abandoned writing brushes"'.

3 The Lotus Sutra (Watson 1993, pp. 35-36) records: "The Buddhas appear in the word solely for this one reason, which is true, the other two are not the truth. Never do they use a lesser vehicle to save living beings and ferry them across. The Buddha himself dwells in this Great Vehicle, and adorned with the power of meditation and wisdom that go with the Law he has attained, he uses it to save living beings. He himself testifies to the unsurpassed way, the Great Vehicle, the Law in which all things are equal. If I used a lesser vehicle to convert even one person, I would be guilty of stinginess and greed, but such a thing would be impossible.".

$4 \quad$ Huijue 慧覺 (fl. 445) and Weide 威德 (fl. 445) (Huijue and Weide 1998, pp. 69-70): “At that time, Jin Cai 金財 shaved off hair and beard, put on a precept robe (kasaya; jiasha 袈桬), and became a novice monk (sramaneraka; sramanera; shami 沙爾). He was old enough to receive complete precepts (upasampanna; upasampada; dajie 大戒; juzu 具足); some monks were ordered to grant him complete precepts. The monks who lintan 臨壇 saluted in proper order", notes: "Lintan: means monks and nuns go to the precept platform (jietan 戒壇) to hold Buddhist ceremonies to grant precepts to others ... ".

\section{References}

Anonymous, trans. 1990, Dedao ticheng xizhang jing 得道梯橙錫杖經. In Taisho Shinshu Daizokyo 大正新修大藏經. Takakusu, Junjiro, and Kaigyoku Watanabe, eds. Taipei: Caituan Faren Fotuo Jiaoyu Jijinhui, vol. 17, pp. 724-26.

Chao, Gongwu. 1990. Junzhai dushu zhi jiaozheng 郡齋讀書志校證. Collated and verified by Meng Sun. Shanghai: Shanghai Guji Chubanshe.

Chen, Shangjun, ed. 1992. Quan Tangshi xushi 全唐詩續拾. In Quan Tangshi bubian 全唐詩補編. Edited and collated by Shangjun Chen. Beijing: Zhonghua Shuju, pp. 637-1796.

Chen, Zhensun. 1987. Zhizhai shulu jieti 直齋書錄解題. Shanghai: Shanghai Guji Chubanshe.

Thomas Cleary, trans. 1993, The Flower Ornament Scripture: A Translation of The Avatamsaka Sutra. Boston: Shambhala Publications, Inc. Conze, Edward, trans and explains. 1972, Buddhist Wisdom Books: The Diamond Sutra . The Heart Sutra. New York, Evanston, San Francisco and London: Harper \& Row, Publishers.

Daoshi, ed. 1990. Zhu jing yao ji 諸經要集. In Taisho Shinshu Daizokyo. Taipei: Caituan Faren Fotuo Jiaoyu Jijinhui, vol. 54, pp. 1-194.

$\mathrm{Hu}$, Zai, ed. 1962. Tiaoxi yuyin conghua (houji) 苕溪漁隱叢話(後集). Collated by Deming Liao. Beijing: Renmin Wenxue Chubanshe.

$\mathrm{Hu}$, Zhenheng. 1981. Tangyin guiqian 唐音癸籤. Shanghai: Shanghai Guji Chubanshe.

Huijue, and Weide, transs. 1998, Xianyu jing 賢愚經. Annotated and translated by Zeyuan Wen, Gang Zhu, Tianran Jiang, Bin Wei and Yanhe Li. Guangzhou: Huacheng Chubanshe.

Huiran, ed. 1990. Zhenzhou Linji Huizhao chanshi yulu 鎮州臨濟慧照禪師語錄. In Taisho Shinshu Daizokyo. Taipei: Caituan Faren Fotuo Jiaoyu Jijinhui, vol. 47, pp. 495-506.

Ji, Yougong, ed. 1989. Tangshi jishi jiaojian 唐詩紀事校箋. Collated and annotated by Zhongyong Wang. Chengdu: Bashu Shushe.

Ji, Yougong, ed. 2013. Tangshi jishi 唐詩紀事. Shanghai: Shanghai Guji Chubanshe.

Jiang, Shaoyu. 1981. Songchao shishi leiyuan 宋朝事實類苑. Shanghai: Shanghai Guji Chubanshe.

Jiang, Yikui. 2019. Yaoshantang waiji (wai yizhong) 堯山堂外紀(外一種). Collated by Jinglin Lv. Beijing: Zhonghua Shuju.

Li, Zhao. 2021. Tang guoshi bu jiaozhu 唐國史補校注. Collated and annotated by Qingfeng Nie. Beijing: Zhonghua Shuju.

John R. McRae, trans. 2000, The Platform Sutra of the Sixth Patriarch. Berkeley: Numata Center for Buddhist Translation and Research.

Ni, Tao, ed. 2017. Lichao shupu huibian 歷朝書譜彙編. In Liuyi zhiyi lu 六藝之一錄. Collated by Weiqiang Qian. Hangzhou: Zhejiang Renmin Meishu Chubanshe, pp. 6040-8295.

Paramiti, trans, Meghasikha, review, Huaidi, verify, and Rong Fang, ed. 2019, The Surangama Sutra 楞嚴經. Translated and Edited by Buddhist Text Translation Society of Dharma Realm Buddhist Association. Beijing: Zongjiao Wenhua Chubanshe.

Peng, Dingqiu, Sanzeng Shen, Zhongne Yang, Conglv Pan, Shihong Wang, Shuben Xu, Dingjin Che, Yi Wang, Sili Zha, and Mei Yu, eds. 1960. Quan Tangshi 全唐詩. Beijing: Zhonghua Shuju.

Ruan, Yue, ed. 1987. Shihua zonggui (qianji) 詩話總龜(前集). Collated by Benchun Zhou. Beijing: Renmin Wenxue Chubanshe.

Shandao, ed. 2013. Yi jing ming wuzhong zengshangyuan yi 依經明五種增上緣義. In Tangdai Jingtu zushi quanji 唐代凈土祖師全集. Collated by Jinggang Zhang. Beijing: Jiuzhou Chubanshe, pp. 202-14.

Shi, Shengnan. 2014. Pei Yue shi jianxi 裴説詩簡析. Youth Years 1: 29.

Sun, Changwu. 2000. Huiyuan yu “Lianshe” chuanshuo 慧遠與“蓮社”傳説. Mt Wutai Researches 3: 9-17.

Sun, Wang, ed. 1982. Quan Tangshi buyi 全唐詩補逸. In Quan Tangshi waibian 全唐詩外編. Beijing: Zhonghua Shuju, pp. 61-322.

Sun, Wang, ed. 1992. Quan Tangshi buyi. In Quan Tangshi bubian. Edited and collated by Shangjun Chen. Beijing: Zhonghua Shuju, pp. 89-318. 
Sun, Yueban. 1985. Yuding Peiwenzhai shuhua pu 御定佩文齋書畫譜. In Wenyuange Siku quanshu 文淵閣四庫全書. Edited by Yongrong · Aisin Gioro and Yun Ji. Taipei: Taiwan Shangwu Yinshuguan, vols. 819-23.

Tao, Zongyi. 2016. Shushi huiyao 書史會要. Collated by Yongming Xu. Beijing: Beijing Shifan Daxue Chubanshe.

Tong, Peiji. 1996. Quan Tangshi chongchu wushou kao 全唐詩重出誤收考. Xi'an: Shaanxi Renmin Jiaoyu Chubanshe.

Tong, Yangnian, ed. 1982. Quan Tangshi xu buyi 全唐詩續補遺. In Quan Tangshi waibian. Beijing: Zhonghua Shuju, pp. 323-710.

Tong, Yangnian, ed. 1992. Quan Tangshi xu buyi. In Quan Tangshi bubian. Edited and collated by Shangjun Chen. Beijing: Zhonghua Shuju, pp. 319-559.

Burton Watson, trans. 1993, The Lotus Sutra. New York: Columbia University Press.

Wu, Haiyuan. 2018. Pei Yue yu Deng Shan shige bijiao yanjiu 裴説與鄧㷋詩歌比較研究. Journal of Guangxi Science E Technology Normal University 4: 53-56.

Xin, Wenfang. 1990. Tang caizi zhuan jiaojian (disi ce) 唐才子傳校箋(第四册). Edited by Xuancong Fu. annotated and verified by Zuzhuan Zhou, Zaiqing Wu, Changping Zhao and Jinhua Jia. Beijing: Zhonghua Shuju.

Xu, Song. 1984. Dengke ji kao 登科記考. Collated by Shouyan Zhao. Beijing: Zhonghua Shuju.

Yijing, trans. 1990, Genben Shuoyiqieyoubu Pinaiye zashi 根本説一切有部毘奈耶雜事. In Taisho Shinshu Daizokyo. Takakusu, Junjiro, and Kaigyoku Watanabe, eds. Taipei: Caituan Faren Fotuo Jiaoyu Jijinhui, vol. 24, pp. 207-414.

You, Mao. 1985. Quan Tang shihua 全唐詩話. Beijing: Zhonghua Shuju.

Fonian Zhu, trans. 1990, Pusa yingluo jing 菩薩瓔珞經. In Taisho Shinshu Daizokyo. Takakusu, Junjiro, and Kaigyoku Watanabe, eds. Taipei: Caituan Faren Fotuo Jiaoyu Jijinhui, vol. 16, pp. 1-126.

Zongmi. 2008. Chanyuan zhu quan ji douxu 禪源諸詮集都序. Collated and annotated by Gaoxing Qiu. Zhengzhou: Zhongzhou Guji Chubanshe. 